\title{
C:
}

\section{Rediscovery of the Eastern Crested Toad (Peltophryne fracta), with Comments on Conservation, Vocalization, and Mating Behavior}

Miguel A. Landestoy T. and Robert Ortíz

Sociedad Ornitológica de la Hispaniola, Santo Domingo, República Dominicana (hispanioland@gmail.com)

Photographs by the senior author.

Deltophryne is a monophyletic genus of toads endemic 1 to the West Indies (Pramuk 2006; Alonso et al. 2012). Three species are endemic to Hispaniola: The Southern Crested Toad (P. guentheri Cochran), which is widely distrib- uted throughout much of the western half of the island; the Hispaniolan Crestless Toad (P. fluviatica Schwartz), known from only two localities in the northwestern Dominican Republic; and the Eastern Crested Toad (P. fracta Schwartz;

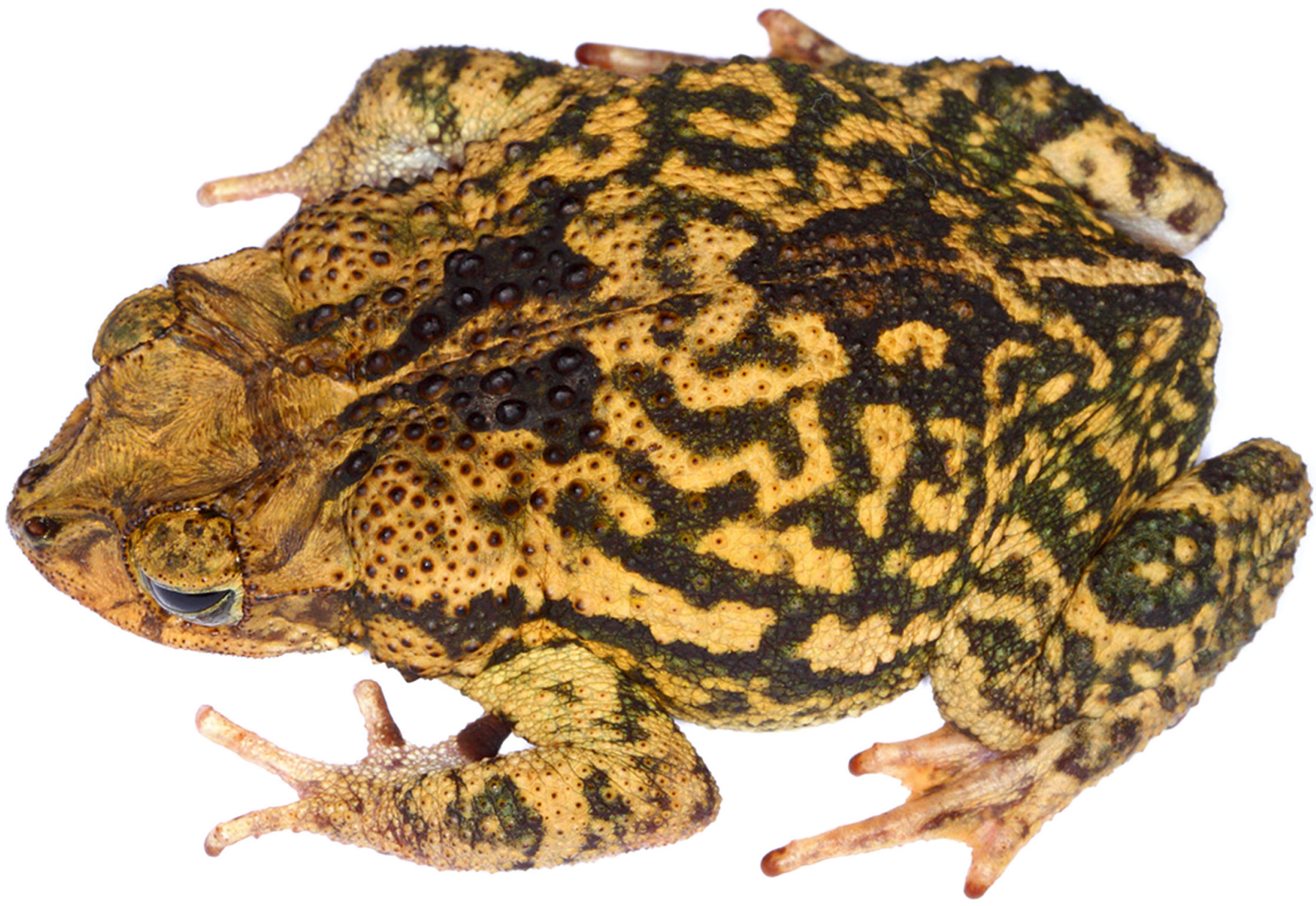

Fig. 1. Male Eastern Crested Toad (Peltophryne fracta) from Santana, $3 \mathrm{~km} \mathrm{~W}$ of Higüey, La Altagracia Province (MNHNSD 23.919). 
Figs. 1-2), which occurs in the extreme eastern Dominican Republic. The relationships of these species remain unclear.

Although geographically isolated, Peltophryne fracta was originally considered a subspecies of $P$. guentheri due to similarities in external morphology (Schwartz 1972). Subsequently, Pregill (1981) justified the recognition of $P$. fracta as a distinct species on the basis of osteological evidence. Powell (1993), based in part on previous information in Schwartz (1972) and Pregill (1981), allopatry, and an audiospectrogram illustrated in Powell (1992), included $P$. fracta among Hispaniolan subspecies that probably warranted recognition as distinct species. The species also was included in checklists in Powell (1996) and Powell et al. (1999). The main diagnostic characters that distinguish it from $P$. guentheri are smaller size, darker dorsal coloration, and a greater interorbital distance. Peltophryne fracta has not been included in any molecular analysis.

Peltophryne fracta has been considered "lost" since the type series was collected (Hedges and Díaz 2010), although the most recent evidence of its existence was specimens and a recording (Powell 1992; Alonso 2011) taken on 5 August 1978 ESE of the type locality and catalogued in the Smithsonian Institution (USNM 259556-64, 8 males and one female, snout-vent length [SVL] 59.7-69.6 mm, mean $65.6 \mathrm{~mm}$, measured from high-resolution images using
ImageJ Software [NIH, Bethesda, Maryland]; 225033 was preserved as a skeleton; USNM tape 49). A male deposited in the Museo Nacional de Historia Natural in Santo Domingo (MNHNSD 23.1) had a SVL of $67 \mathrm{~mm}$. Labeled only with the year of collection "2000," it was collected in Las Limas, Matachalupe, W of Higüey, La Altagracia Province, by J. Idalgo. Extensive surveys in the region in 2003 failed to find any individuals (Hedges et al. 2004). Because the species had not been found since the 1970s and occurs in degraded habitat, it was listed as endangered in the IUCN Red List of Threatened Species (Hedges et al. 2004).

On the night of 1 July 2011, during apparently favorable weather conditions, we began our search for the species at about $2000 \mathrm{~h}$ approximately $15 \mathrm{~km}$ west of the type locality (1.1 km W of Higüey, La Altagracia Province). Driving along HW DR-4 at 2320 h, we located a small chorus of Peltophryne fracta in a rainwater-filled roadside ditch near a construction project in a developing (urban) area in the town of Santana, $3 \mathrm{~km} \mathrm{~W}$ of Higüey, La Altagracia Province (elevation 128 $\mathrm{m})$. Of the three males encountered, two were deposited in the Museo Nacional de Historia Natural of Santo Domingo catalog numbers MNHNSD 23.919-20. Snout-vent lengths were 72.5 and $71.5 \mathrm{~mm}$, respectively, exceeding the upper size limit previously recorded for males of the species (males to $67 \mathrm{~mm}$ SVL; Schwartz 1972).

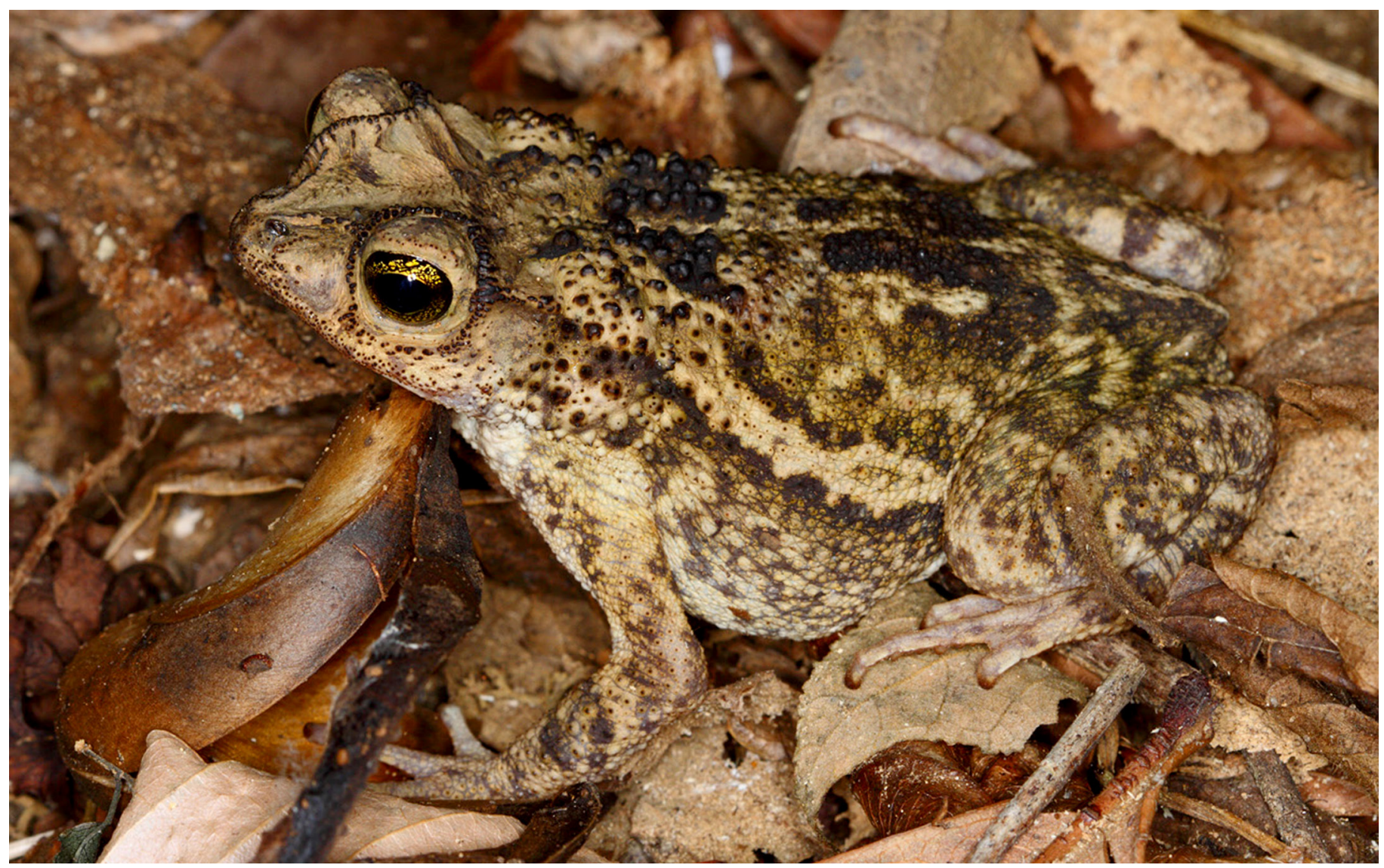

Fig. 2. Female Eastern Crested Toad (Peltophryne fracta; MALT 84) from Rancho de Mana, La Altagracia Province. 


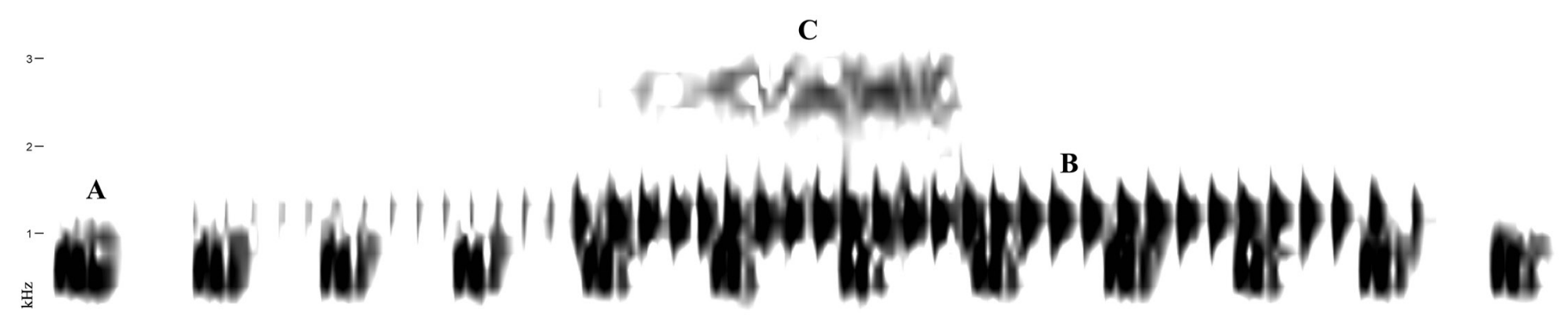

Fig. 3. Spectrogram of a sequence of calls in a chorus showing spectral partitioning in the dominant frequencies of three anurans: A. Rhinella marina (0.56 $\mathrm{kHz})$; B. Peltophryne fracta $(1.12-1.31 \mathrm{kHz})$; C. Osteopilus dominicensis $(2.62 \mathrm{kHz})$. A trace of the call of a distant individual $P$. fracta is evident before the stronger signal of a nearby male. Recorded and analyzed in WAV format (Marantz PMD661 field recorder and Sennheiser ME 67 shotgun microphone) on 1 July $2011(2320 \mathrm{~h})$ at the same locality as the individual in Fig. 1 . No temperature data were taken, but air temperature was $25.4{ }^{\circ} \mathrm{C}$ at $2000 \mathrm{~h}$ in September 2014.

The chorus, besides $P$. fracta and introduced Cane Toads (R. marina), also included a widely distributed endemic hylid, the Hispaniolan Laughing Treefrog (Osteopilus dominicensis). An analysis of a sequence of the audiospectrogram involving all three species shows spectral partitioning in the dominant frequencies of calls from each species (Fig. 3).

Several aquatic habitats occur in the vicinity of the type locality; these include ditches, cattle ponds, and streams and rivers. During three additional visits to the area on August, September, and October 2014, while inspecting habitats near the type locality, we detected vocalizations by several other anuran species (Rhinella marina, Lithobates catesbeianus, Eleutherodactylus abbotti, E. flavescens, E. inoptatus, E. weinlandi, Hypsiboas heilprini, Osteopilus dominicensis, O. pulchrilineatus), but no $P$. fracta. However, despite not detecting any breeding choruses of $P$. fracta, we did find two adult females on two different occasions near Rancho de Mana $(5 \mathrm{~km}$ NNW Santana, elevation $\sim 113 \mathrm{~m}$ ), one on 4 August moving along a dirt road and another found by a local resident on 21 October sitting below the dripping tap of a water tank in a domestic setting $\left(2050 \mathrm{~h}\right.$, air temperature $24.4^{\circ} \mathrm{C}$, relative humidity $85 \%$ ). The female found in August was preserved (SVL $68.3 \mathrm{~mm}$; MALT 84) and found to contain immature oocytes; the other female (SVL $77.1 \mathrm{~mm}$ ) was kept alive and taken to the national zoo for an ex-situ breeding program initiative. Neither female vocalized, but both performed vertical head vibrations while being handled, as we have observed in males of the species and which apparently also are used by $P$. guentheri as release calls (unpubl. data).

Our visit on 4 August followed the passing of tropical storm Bertha, but rainfall seemingly was insufficient to trigger breeding activity in $P$. fracta. Schwartz (1972) suggested that breeding activity might occur under highly specific climatic conditions given that the habitat is more mesic than that occupied by $P$. guentheri. The months during which breeding had been recorded were June, August, and September, although two males (paratypes KU263923-24) were collected in July on a road after rain (Schwartz 1972). Our discovery of a breeding chorus in July adds to the recorded temporal pattern of reproductive activity, which also corresponds to the Atlantic hurricane season that runs from the beginning of June through the end of November. Peltophryne fracta is difficult to find outside the breeding season (Hedges et al. 2004), so extended monitoring in the vicinity of the type locality is needed to understand activity patterns and non-breeding movements (i.e., migration, foraging, dispersal).

Introduced Cane Toads are potential competitors and predators of Eastern Crested Toads, as are introduced American Bullfrogs (L. catesbeianus), which are commonly encountered in ponds and slow moving sections of rivers. These invasive species likely aggravate habitat threats affecting the remaining populations of $P$. fracta. Habitat threats (Hedges et al. 2004) include intensive cattle ranching, agriculture, and urbanization. The rate of urban development in the outskirts of the city of Higüey, neighboring towns, and along roads is accelerating. New buildings (Fig. 4) and an ongoing development project are affecting the exact site of the breeding event we observed in July 2011. Remaining forested areas are limited to narrow strips along riparian systems and large plots have been devoted to sod destined for landscaping, especially for regional tourist developments and along new highways. The female Eastern Crested Toad found under the dripping tap of a water tank was near such a plot. We also observed several foraging Cane Toads on crops of sod.

Information on the advertisement call of $P$. fracta was presented in Powell (1992) and Alonso (2011). Pregill (1981) and Powell et al. (1996) mentioned differences with the call of $P$. guentheri, but neither provided any details. The advertisement call of $P$. fracta $(\mathrm{N}=12$; one individual) involves a more distinctive diphthong, an "oo-aaahhh" of lower frequency $(1.12 \mathrm{kHz})$ evident during the initial pulses (approx. the first fourth of the call duration), that increases sharply in frequency during the remaining pulses to $1.31 \mathrm{kHz}$ (MALT, unpubl. data). This contrasts with the monosyllabic call of P. guentheri $(\mathrm{N}=6$, based on single individuals from three localities in northern, Arroyo Clavijo and Río Maguana, and southern, Postrer Río, populations), a flatter "waaahnk" (Schwartz's 1972 onomatopoeic description), in which the 


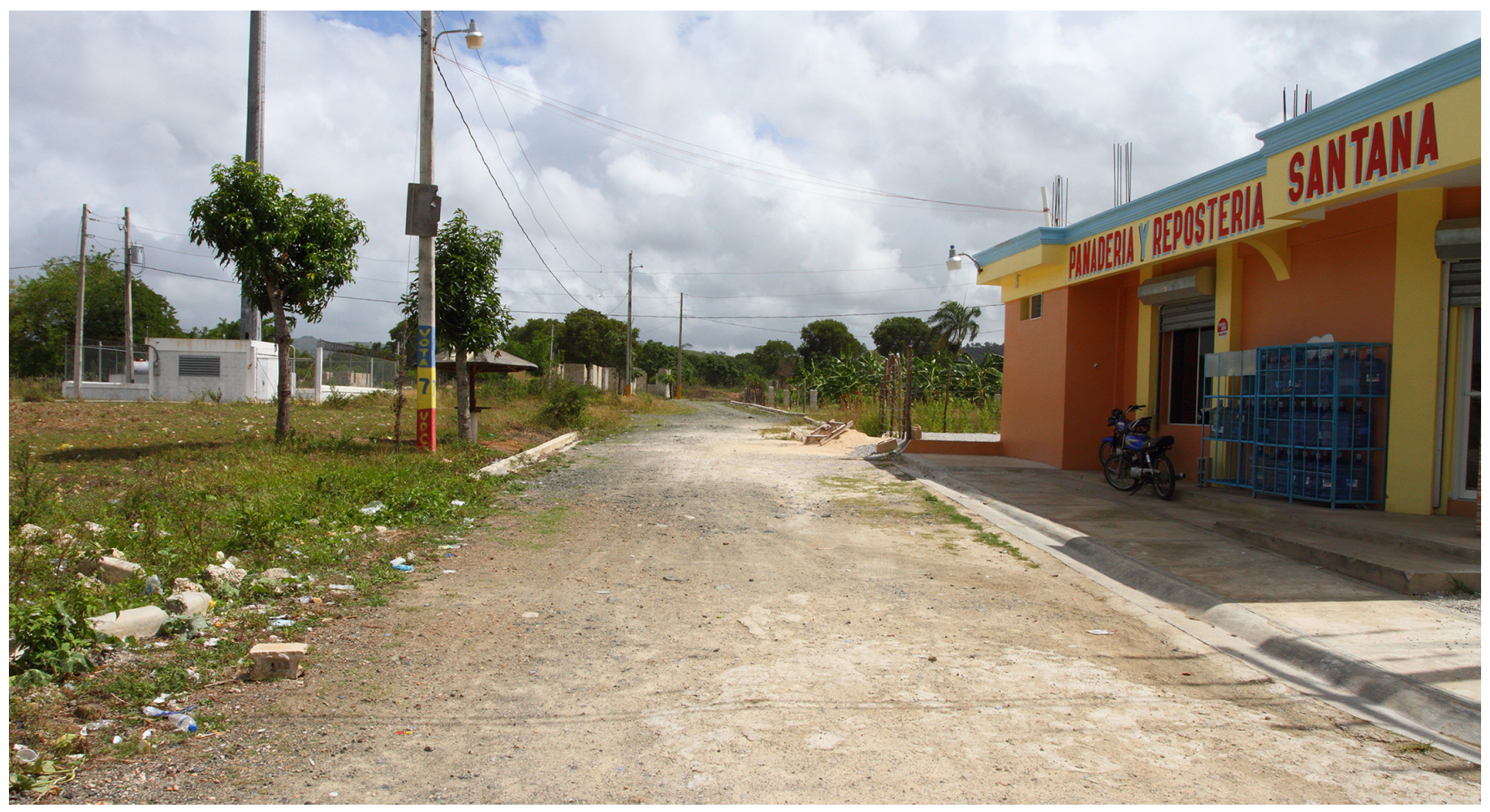

Fig. 4. The site of our rediscovery of the Eastern Crested Toad (Peltophryne fracta) on 5 August 2014 showing new buildings, concrete curbs, and a sidewalk.

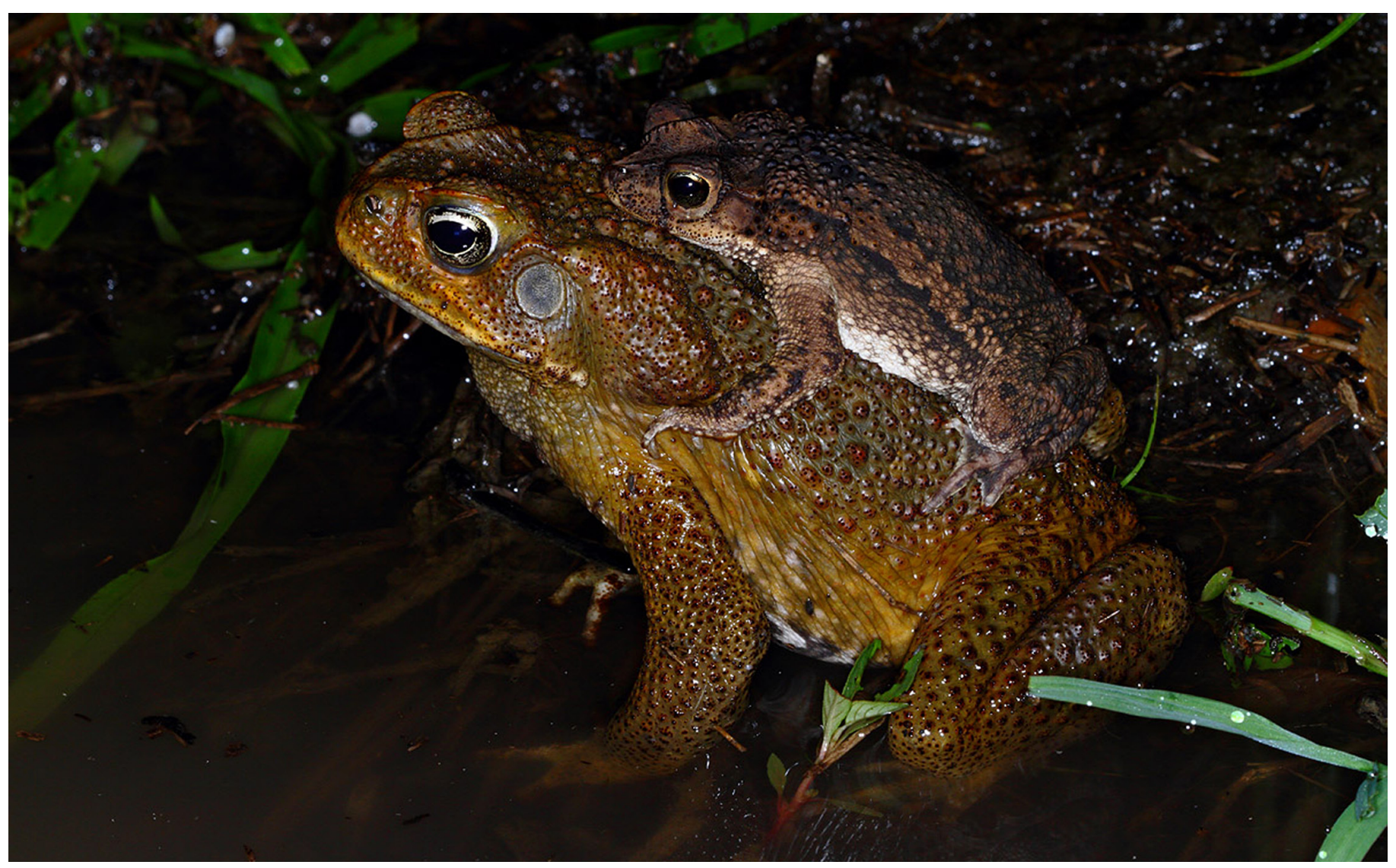

Fig. 5. Male Eastern Crested Toad (Peltophryne fracta) engaged in interspecific homosexual amplexus with a Cane Toad (Rhinella marina). 

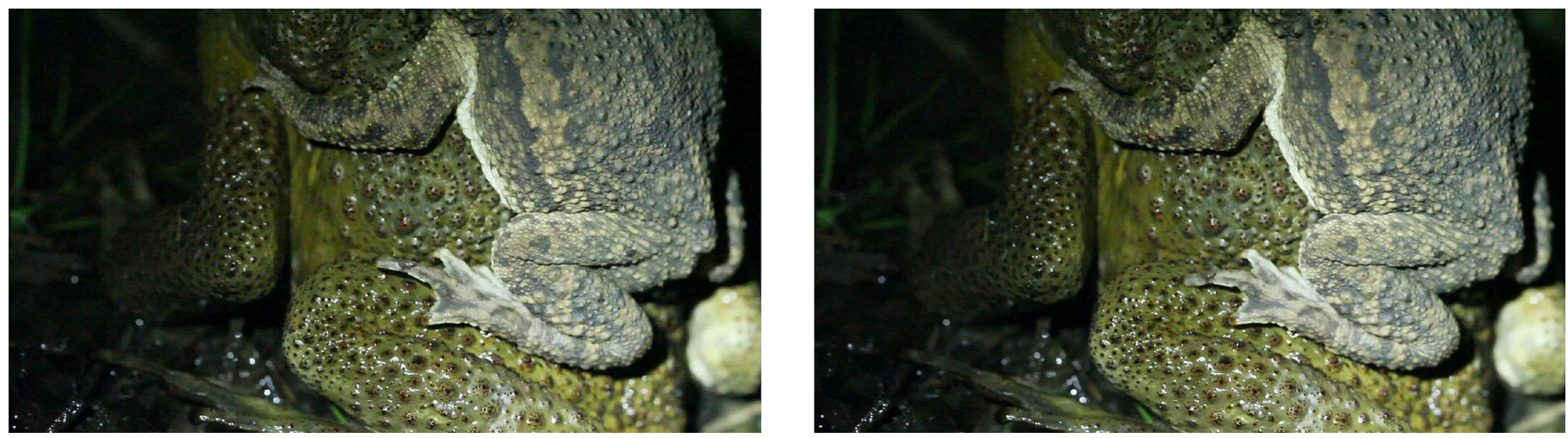

Fig. 6. Video frames showing a male Eastern Crested Toad (Peltophryne fracta) toe-twitching while amplecting a male Cane Toad (Rhinella marina) at Santana, $3 \mathrm{~km}$ W Higüey.
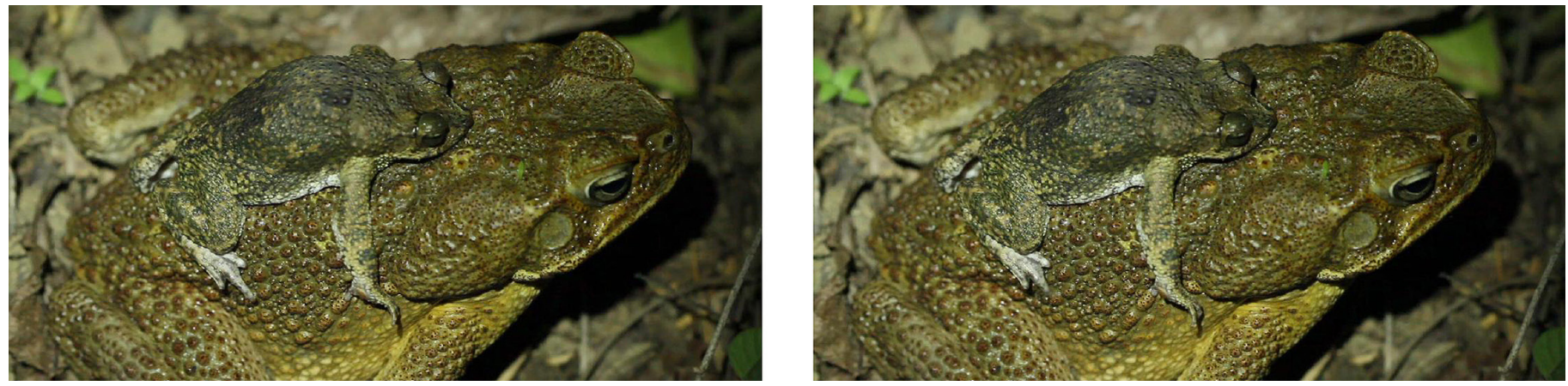

Fig. 7. Video frames showing a male Southern Crested Toad (Peltophryne guentheri) toe-twitching while amplecting a male Cane Toad (Rhinella marina) on 5 May 2014 at Arroyo Clavijo, Santiago Rodríguez Province.

flatter pitch remains the same throughout the call or either rises or decreases progressively near the last half or fourth of the call. However, both species exhibit the same frequency range $(1.12-1.31 \mathrm{kHz})$. We acknowledge that a larger sample size and considerations of individual size and weather variables are needed for a more extensive and accurate comparative analysis.

Reproductively active male bufonids frequently attempt amplexus with any moving object of about their own size (Blair 1947). One male $P$. fracta was engaged in an interspecific homosexual amplexus with a male Cane Toad (Figs. 5 and 6). We observed the male $P$. fracta stroking or tapping the hindlimb of the $R$. marina with the middle (IV) toes of both feet in a rapid, vertically oriented fashion (Fig. 6; https:// youtu.be/JhiNC4ii5CI). The senior author has observed essentially similar behavior in a male $P$. guentheri amplecting and stroking the dorsolateral region of a male $R$. marina (Fig. 7; https://youtu.be/RwIkrH2q5C8). Toe-movement behavior (toe-twitching, toe-waving, toe-tapping, pedal luring) is widely reported in anurans, although the terminology has been confusing (Sloggett and Zeilstra 2008). Regardless, such movements appear to be linked exclusively to predatory strategies (Murphy 1976; Radcliffe et al. 1986; Bertoluci 2002; Hagman and Shine 2008; Sloggett and Zeilstra 2008; McFadden et al. 2010), including those of several bufonid genera that have been reported to perform toe-twitching (Radcliffe et al. 1986; Hagman and Shine 2008; Sloggett and Zeilstra 2008). We cannot relate our observations to predatory behavior. Instead, we believe its function might have been the tactile stimulation of a potential mate during amplexus. An amateur video clip on the Internet shows amplected toads (https://youtu.be/PhJnQRdNFFg) performing similar behavior, but the species was not identified nor was any additional information provided.

\section{Acknowledgements}

We thank the Rufford Foundation for funding the project "Ecology and Conservation of Hispaniolan Bufonids (Peltophryne)" and the Ministerio de Medio Ambiente y Recursos Naturales of the Dominican Republic for issuing a research permit. The Museo de Historia Natural Prof. Eugenio Marcano provided facilities to work. Antonio Tosto, Berenice Mercedes, Yoani Dávila, Osiris Báez, and Hector Rijo helped with fieldwork. Luke Mahler examined specimens and consulted Schwartz's field notebooks at the Biodiversity Institute at the University of Kansas (KU). Roy McDiarmid, James Poindexter, Steve Gotte, and Addison Wynn of the National Museum of Natural History (USNM) provided information and photographs of specimens. We also thank the administration and staff of the Parque Zoológico 
Nacional (ZOODOM) for supporting an ex-situ program initiative on toads in the genus Peltophryne.

\section{Literature Cited}

Alonso, R. 2011. Origen y diversificación del género Peltophryne (Amphibia: Anura: Bufonidae) en Cuba. Tésis presentada en opción al grado de Doctor en Ciencias Biológicas. Universidad de La Habana, Cuba.

Alonso, R., A.J. Crawford, and E. Bermingham. 2012. Molecular phylogeny of an endemic radiation of Cuban toads (Bufonidae: Peltophryne) based on mitochondrial and nuclear genes. Journal of Biogeography 39:434-451.

Bertoluci, J. 2002. Pedal luring in the leaf-frog Phyllomedusa burmeisteri (Anura, Hylidae, Phyllomedusinae). Phyllomedusa 1:93-95.

Blair, A.P. 1947. The male warning vibration in Bufo. American Museum Novitates 1344:1-7.

Hagman, M. and R. Shine. 2008. Deceptive digits: The functional significance of toe waving by cannibalistic Cane Toads, Chaunus marinus. Animal Behaviour 75:123-131.

Hedges, S.B. and L.M. Díaz. 2010. The conservation status of amphibians in the West Indies, pp. 31-47 In: A. Hailey, B. Wilson, and J. Horrocks (eds.), Conservation of Caribbean Island Herpetofaunas. Volume 1: Conservation Biology and the Wider Caribbean. Brill, Leiden, The Netherlands.

Hedges, S.B., S.J. Incháustegui, M. Hernández, and R. Powell. 2004. Peltophryne fracta. In: IUCN 2011. IUCN Red List of Threatened Species. <www.iucnredlist.org>.

Mcfadden, M., P.S. Harlow, and D. Purcell. 2010. Toe-twitching during feeding in the Australian myobatrachid frog, Pseudophryne corroboree. Herpetological Review 41:153-154.
Murphy, J.B. 1976. Pedal luring in the leptodactylid frog, Ceratophrys calcarata Boulenger. Herpetologica 32:339-341.

Powell, R. 1992. Peltophryne guentheri. Catalogue of American Amphibians and Reptiles 535:1-4.

Powell, R. 1993. Comments on the taxonomic arrangement of some Hispaniolan amphibians and reptiles. Herpetological Review 24:135-137.

Powell, R., R.W. Henderson, K. Adler, and H.A. Dundee. 1996. An annotated checklist of West Indian amphibians and reptiles, pp. 51-93 + 8 pls. In: R. Powell and R.W. Henderson (eds.), Contributions to West Indian Herpetology: A Tribute to Albert Schwartz. Contributions to Herpetology, volume 12. Society for the Study of Amphibians and Reptiles, Ithaca, New York.

Powell, R., J.A. Ottenwalder, and S.J. Incháustegui. 1999. The Hispaniolan herpetofauna: Diversity, endemism, and historical perspectives, with comments on Navassa Island, pp. 93-168. In: B.I. Crother (ed.), Caribbean Amphibians and Reptiles. Academic Press, San Diego, California.

Pramuk, J.B. 2006. Phylogeny of South American Bufo (Anura: Bufonidae) inferred from combined evidence. Zoological Journal of the Linnean Society 146:407-452.

Pregill, G.K. 1981. Cranial morphology and evolution of the West Indian toads (Salientia: Bufonidae): Resurrection of the genus Peltophryne Fitzinger. Copeia 1981:273-285.

Radcliffe, C.W., D. Chiszar, K. Estep, J.B. Murphy, and H.M. Smith. 1986. Observations on pedal luring and pedal movements in leptodactylid frogs. Journal of Herpetology 20:300-306.

Schwartz, A. 1972. The native toads (Anura, Bufonidae) of Hispaniola. Journal of Herpetology 6:217-231.

Sloggett, J.J. and A. Zeilstra. 2008. Waving or tapping? Vibrational stimuli and the general function of toe twitching in frogs and toads (Amphibia: Anura). Animal Behaviour 76:e1-e4. 